\title{
Degeneration of Alpine Steppe Vegetation around Sary-Tash Village, Kyrgyz Republic
}

\author{
Teruo ARASE ${ }^{1}$, Jie $\mathrm{LIU}^{2}$ and Teiji WATANABE ${ }^{3}$
}

\begin{abstract}
We investigated whether overgrazing has caused the degeneration of steppe vegetation around SaryTash Village (southern Kyrgyz Republic) at an elevation of 3,100 to 3,400 m. Six vegetation lines, combining slope direction (N, north; S, south) with elevation zone (1, high; 2, middle; 3 , low) and containing 8 plots $(2 \mathrm{~m} \times 2 \mathrm{~m})$ per line, were established. The line of S2 lies on the slope of degenerated vegetation. In each plot, species composition, coverage, plant height, and plant growth form were surveyed in July 2012. V-values were calculated as an estimate of above-ground biomass. As a result, 6 species, including Carex sp., Artemisia sp., and Deschampsia caespitosum, were distributed along all lines with relatively high consistency and coverage classes, and several species including those in the Poaceae, Asteraceae, and Brassicaceae were characterized along each line. The similarity of species composition was significantly smaller among the south-oriented lines (with CC ranging from 0.309 to 0.339 ) than among the north-oriented lines (CC from 0.418 to 0.509 ). Analysis of variance proved that south-facing slopes were covered with a tall, sparse community and north-facing slopes were covered with a short, dense community. Differences in V-values and total number of species were not significant among the lines. The half-change interval (HC), calculated from the similarity in species composition between plots, was significantly smaller in S2 and S3 (the HC values were 2.1 and 1.9 plots, respectively) than the other lines (HC ranged from 5.3 to 11.3). This suggests that the replacement of species was intense (i.e., beta diversity was high) in south-facing slopes, except for S1. The growth form spectrum in S2, comprising a smaller percentage of ' $\mathrm{t}$ ' (tussoks) and larger percentages of 'r-e' (erect-form forbs with rosettes) and 'b' (branched forms) than the other lines, was inconsistent with the changes generally reported as being caused by grazing. Consequently, we cannot attribute the degeneration of vegetation in S2 to grazing alone. Other environmental factors deserve attention in order to explain the cause of degeneration.
\end{abstract}

Key words : The Kyrgyz Republic, alpine steppe, growth form, grazing, slope direction, beta diversity

\section{I . Introduction}

Degeneration of grassland by overgrazing is a serious problem for the present vegetation, which has prompted much research, especially in the alpine zone of Central Asia and China in Northern Eurasia (Kawanabe et al., 1991; Kawanabe et al., 1998; Kawamura et al., 2005; Schmidt, 2005; Cheng et al., 2008; Li and Huang, 2011; Taft et al., 2011). However, attributing the degeneration of grassland to grazing requires inspection. At present, other probable causes exist, including physical environmental effects such as global

\footnotetext{
${ }^{1)}$ Faculty of Agriculture, Shinshu University, Japan

${ }^{2)}$ Graduate School of Environmental Science, Hokkaido University, Japan

${ }^{3)}$ Faculty of Environmental Earth Science, Hokkaido University, Japan
} 


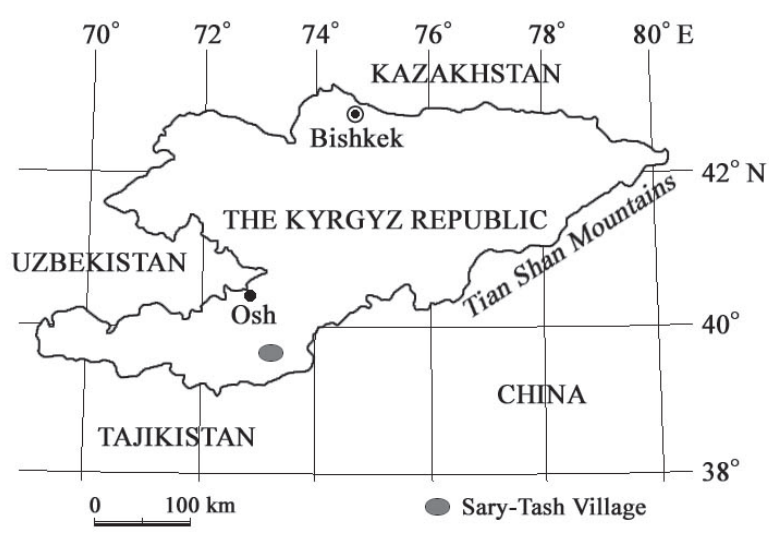

Fig. 1. Location of the Sary-Tash village, Kyrgyz Republic

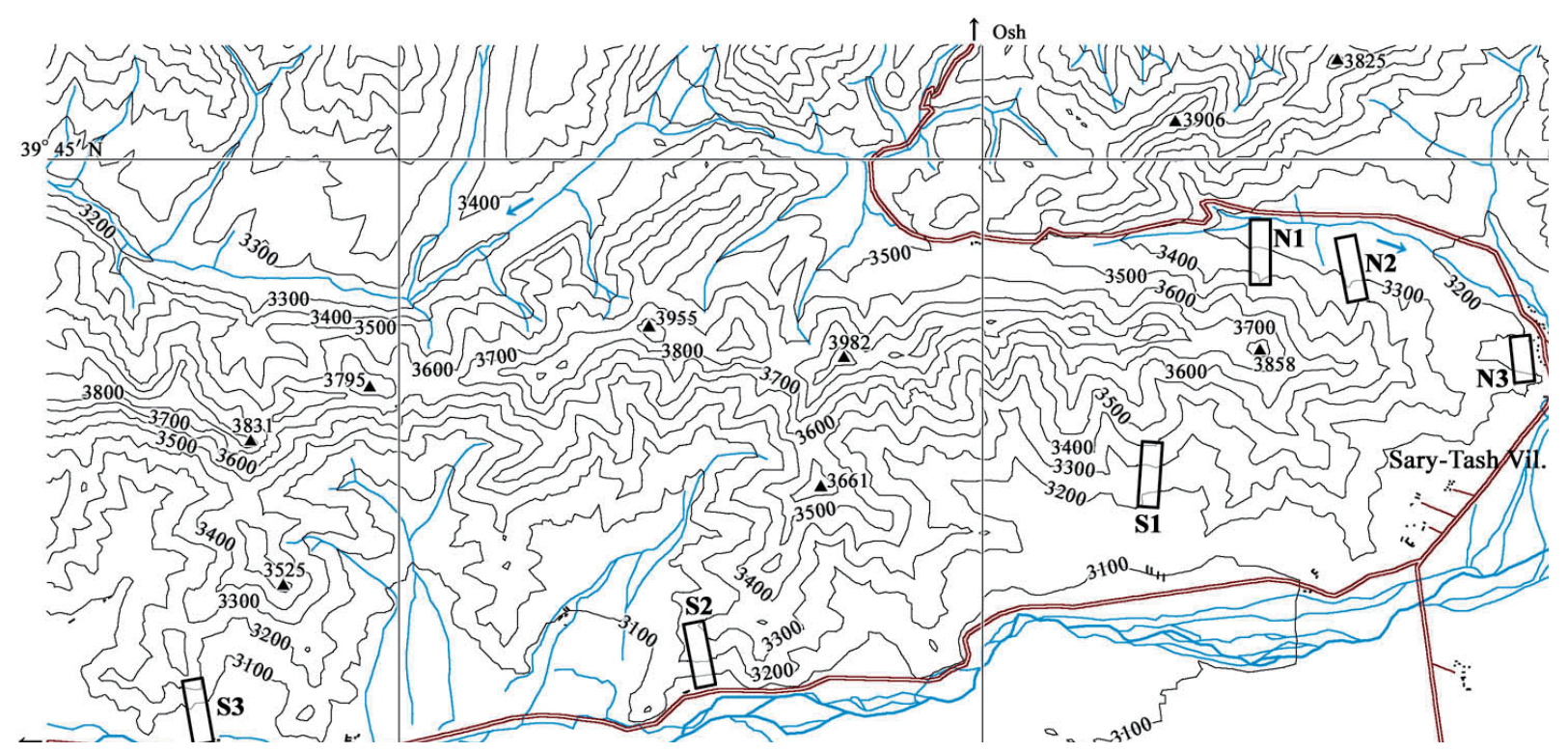

Fig. 2. Geomorphology of the research area and locations of lines for the vegetation survey

warming, and artificial influences such as tourism (Watanabe et al., 2008).

In the steppes of northern Eurasia, nomadic tribes have bred horses, cattle, sheep, and goats since the early Bronze Age. Many tribes and empires alternately expanded and declined in this region (Chibilev and Bogdanov, 2009). Beginning in the early 20th century, the Soviet Union promoted the domiciliation of nomadic people and established permanent agricultural land. After the collapse of the Soviet Union in 1991, demands for recreation and tourism from foreign countries increased (Schmidt, 2005). These changes in the social situation, in addition to grazing, are considered to have influenced the vegetation in
Central Asia. The Kyrgyz Republic is well-known for the scenery of its Tien-Shan and Pamir-Alai mountain systems. About $25 \%$ of the land area in the Kyrgyz Republic is more than 3,500 $\mathrm{m}$ above sea level and is dominated by snow, glaciers, and rock. Land cover below 3,500 m includes predominantly steppe grasslands with some forested areas of conifers and broad-leaved trees such as walnut (Schmidt, 2005; Taft et al., 2011).

As one of such center of livestock grazing and tourism, we focused on the area around SaryTash Village (administratively, Sary-Tash and Taldy-Suu villages; Figs. 1 and 2), Osh Province, southern Kyrgyz Republic. This area is located on the north of the Pamir-Alai mountain system, 
with an elevation of 3,000 to $3,500 \mathrm{~m}$; the landscape is dominated by alpine steppe on relatively gentle slopes above the forest line (Figs. 3-5). In our survey of the residents, some answered that some slopes showed degenerated vegetation, but others answered that the slopes had maintained their present state for several decades (Watanabe et al., unpublished data; to be published elsewhere). Intensity of grazing and route of transhumance in the area are being surveyed in separate studies.

Grazing pressure is reported to directly cause a decrease in plant height and biomass (Painter et al., 1993; Nishiwaki et al., 1999), stripping of vegetation and invasion of annual plants (Daubenmire and Colwell, 1942; Kawagoe and Baba, 1992; Kawanabe et al., 1998), dominance by allelopathic plants (Li and Huang, 2011), and replacement by nonpalatable species (Cheng et al., 2008). It is also reported to cause deterioration of soil directly and indirectly, for example, by erosion, alkalization, and decreased capacity for water absorption (Daubenmire and Colwell, 1942; Tamura and Cheng, 2009). Monitoring vegetation changes using satellite images has been promoted in order to capture both wide-area and dramatic changes such as desertification or disappearance of forests (e.g., Kawamura et al., 2005).

In the present study, we considered whether overgrazing has caused the degeneration of steppe vegetation around Sary-Tash Village. Six vegetation lines, combining slope direction (north, south) with elevation zone (high, middle, low), were established and surveyed phytosociologically. Data were analyzed, especially from the viewpoint of growth forms related to grazing pressure.

\section{II . Methods}

\section{Vegetation survey}

In the research area, 6 lines were established for a vegetation survey in July 2012. These lines comprised combinations of two slope directions ( $\mathrm{S}$, south; $\mathrm{N}$, north) with three elevation zones (1,

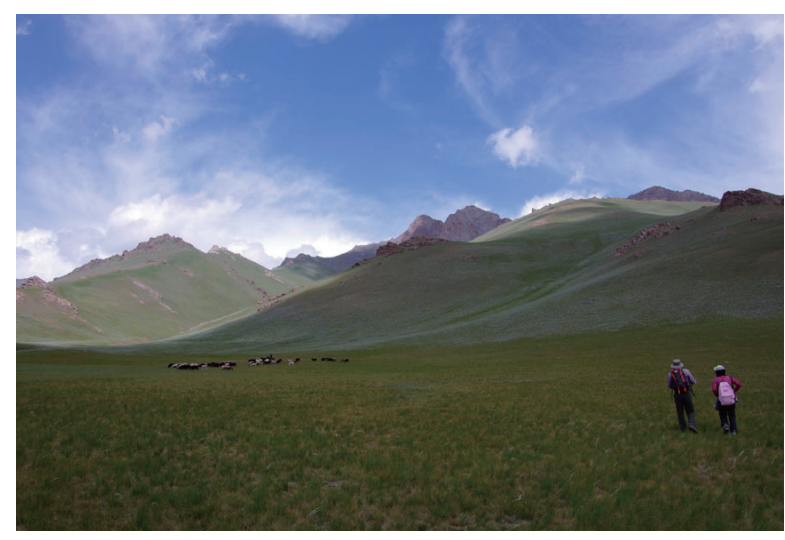

Fig. 3. Landscape of alpine steppe vegetation in the research area

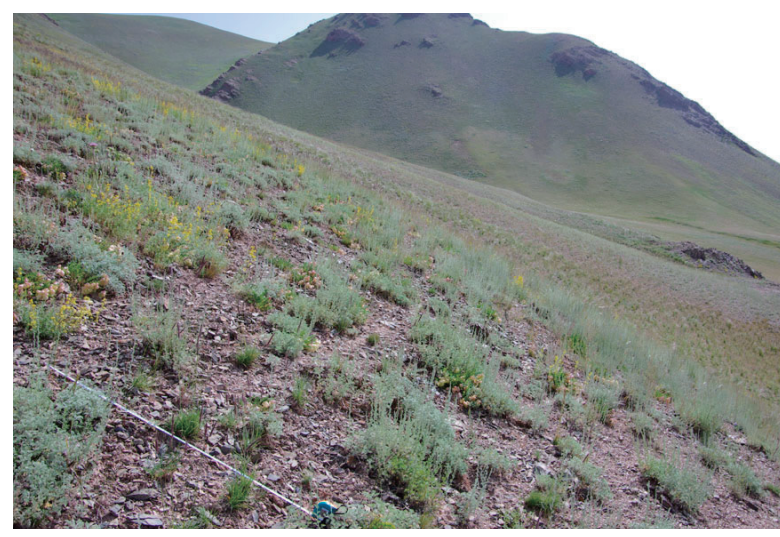

Fig. 4. 'Degenerated' vegetation in a southern slope (S2)

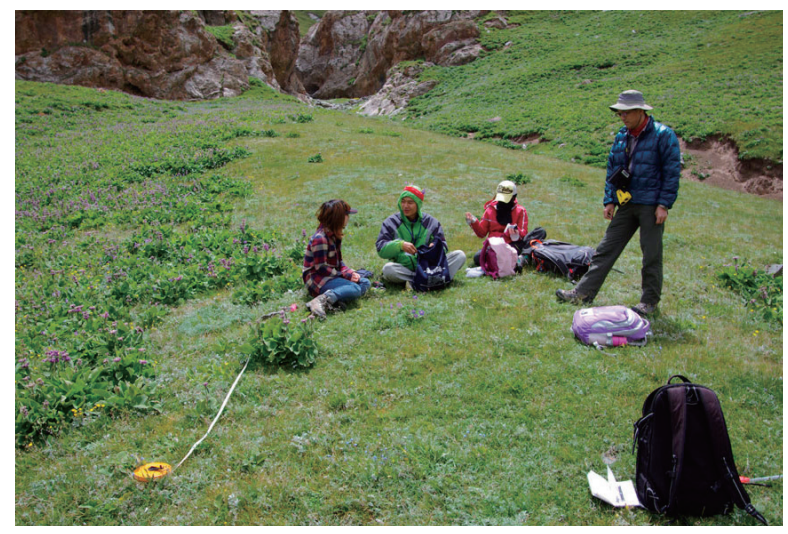

Fig. 5. Dense vegetation in a northern slope (N1)

from 3,400 to $3,300 \mathrm{~m}$; 2 , from 3,300 to $3,200 \mathrm{~m}$; and 3, from 3,200 to 3,100 m). The line of $\mathrm{S} 2$ lies on the slope of degenerated vegetation. Figure 2 shows the location of each line.

Eight survey plots $(2 \mathrm{~m} \times 2 \mathrm{~m}$ per plot) were set within each vegetation line, at approximately regular intervals of elevation. 
In each plot, coverage and height of each plant species present were measured. Plant coverage was ranked using classes from the Braun-Blanquet scale as follows:

+ :vegetation was sparse and covered an area less than $1 \%$ of the total plot;

1: vegetation covered between 1 and $10 \%$ of total plot area;

2: vegetation covered between 10 and $25 \%$ of total plot area;

3: vegetation covered between 25 and $50 \%$ of total plot area;

4: vegetation covered between 50 and $75 \%$ of total plot area;

5: vegetation covered more than $75 \%$ of total plot area.

Growth form of each plant species was determined by on-the-spot observation, based on the original classification by Gimingham (1951) and its modification by Numata (1965). The classification in our survey is as follows:

t: tussocks (e.g., gramineous grasses and sedges); r-e: erect-form forbs with rosettes (e.g., Artemis$i a$ and Aster species);

p-b: forbs with prostrate base and branched assurgent stems (e.g., Astragalus species); r: rosettes (e.g., Taraxacum species); b: branched forms (e.g., Myosotis species); e: erect forms (e.g., Chenopodium species).

\section{Data analyses}

V-values (Kawada et al., 2005; Arase, 2012) were calculated as an estimate of above-ground biomass for each plot. This value, volume per area $\left(\mathrm{m}^{3} \cdot \mathrm{m}^{-2}\right)$, is calculated from the sum of multiplying each species' coverage and height. Values for coverage percentage used in the calculation of V-values were obtained by converting each coverage class into a single percentage (e.g., class 5 , which comprised coverage between 75 and 100\%, was converted to a value of $87.5 \%$ ).

Consistency of each species was determined on each vegetation line by its presence out of 8 plots as follows:

I : less than $20 \%$, i.e., present in only 1 plot;

II : from 20 to $40 \%$, i.e., present in 2 or 3 plots;

III : from 40 to $60 \%$, i.e., present in 4 plots;

IV : from 60 to $80 \%$, i.e, present in 5 or 6 plots;

$\mathrm{V}$ : more than $80 \%$, i.e., present in 7 or 8 plots.

Each species was rearranged phytosociologically, based on the species with middle consistencies of II, III and IV.

As an index of similarity between vegetation lines, we employed Jaccard's coefficient of community (CC). This index is obtained from a cross table of presence or absence of species:

$$
\mathrm{CC}=\mathrm{c} /(\mathrm{a}+\mathrm{b}-\mathrm{c}) \text {, }
$$

where a means the number of species present on line $\mathrm{A}, \mathrm{b}$ means that on line $\mathrm{B}$, and $\mathrm{c}$ means that on both lines $\mathrm{A}$ and $\mathrm{B}$.

To express the changes in species composition along the environmental gradient on each slope (which corresponds to the difference in microelevation among 8 plots in the present study), a half-change (HC) value (Whittaker, 1960) was measured on each vegetation line. $\mathrm{HC}$, analogous to the half-life of radioactive elements, means the distance with $50 \%$ similarity of species composition. A small value of $\mathrm{HC}$ suggests that a slight difference in the gradient causes intensive replacement of species (i.e., high beta diversity).

$$
\mathrm{M}(d)=\mathrm{A} \cdot \exp (-\mathrm{B} \cdot d),
$$$$
\mathrm{HC}=\log (2 / \mathrm{B}) \text {, }
$$

where $d$ means the interval between 2 out of the 8 plots, $\mathrm{M}(d)$ means the average similarity, and $\mathrm{A}$ and B are constants. Jaccard's CC was employed as the measure of similarity between plots. A and $B$ were estimated for each vegetation line by a regression analysis using reliable data from $d=1$ to 5 (M $(d)$ can also be calculated up to $d=6$ and 7 , but the value will be unreliable since there are only 2 and 1 similarity data points, respectively, out of the 8 plots).

After classifying plant species into the above 6 growth form types, the V-value of each type was subtotaled and converted into a percentage out of 
Table 1. Species composition for each research line

\begin{tabular}{|c|c|c|c|c|c|c|}
\hline $\begin{array}{r}\text { Survey No. } \\
\text { Line No. }\end{array}$ & $\begin{array}{c}5 \\
\mathrm{~S} 1\end{array}$ & $\begin{array}{c}4 \\
\text { S2 }\end{array}$ & $\begin{array}{c}1 \\
\text { S3 }\end{array}$ & $\begin{array}{c}3 \\
\text { N1 }\end{array}$ & $\begin{array}{c}2 \\
\mathrm{~N} 2\end{array}$ & $\begin{array}{c}6 \\
\text { N3 }\end{array}$ \\
\hline Carex sp. & $V+-1$ & II + & V $1-3$ & II $1-3$ & V $1-3$ & V $1-3$ \\
\hline Artemisia sp. 1 & IV $1-3$ & IV +-3 & IV $1-2$ & IV +-1 & $\mathrm{I}+$ & IV +-1 \\
\hline Deschampsia caespitosum & IV +-3 & $\mathrm{II}+$ & II $1-2$ & IV $2-3$ & IV $1-3$ & II $2-3$ \\
\hline Myosotis silvatica & $\mathrm{IV}+$ & $\mathrm{III}+$ & $\mathrm{III}+$ & $\mathrm{V}+-1$ & II +-1 & II + \\
\hline Astragalus sp.1 & $\mathrm{V}+-1$ & I 1 & $\mathrm{I}+$ & $\mathrm{V}+-3$ & III +-1 & IV +-3 \\
\hline Euphrasia sp. & $\mathrm{II}+$ & II +-1 & I + & IV + & $\mathrm{I}+$ & II +-1 \\
\hline Taraxacum sp. & $V+-1$ & $\cdot$ & IV + & $\overline{I V+-2}$ & $\mathrm{~V}+$ & $\mathrm{V}+-1$ \\
\hline Festuca sp. & $V+-4$ & . & II $2-3$ & IV +-2 & III $2-3$ & V $1-3$ \\
\hline Stipa alpina & IV +-1 & II +-1 & $\mathrm{~V}+-2$ & . & $\mathrm{II}+$ & $\mathrm{I}+$ \\
\hline Lepidium sp. & $\mathrm{II}+$ & $\mathrm{II}+$ & $\mathrm{III}+$ & . & $\mathrm{I}+$ & II + \\
\hline Trisetum sp. & II $1-2$ & IV +-1 & . & $\mathrm{I}+$ & II + & . \\
\hline Pedicularis apodochila & II + & $\mathrm{I}+$ & . & $\mathrm{II}+$ & $\cdot$ & $I+$ \\
\hline Poa sp. & $\mathrm{I}+$ & II +-1 & IV +-1 & II $1-2$ & III +-3 & . \\
\hline Aster sp. 1 & . & $\mathrm{II}+$ & $\mathrm{I}+$ & IV +-1 & $\mathrm{II}+$ & IV +-1 \\
\hline Potentilla sp.1 & . & IV +-1 & II 1 & I 1 & $V+-3$ & . \\
\hline Arabis sp.1 & . & $\mathrm{II}+$ & $\mathrm{III}+$ & . & $\mathrm{II}+$ & . \\
\hline Potentilla sp.2 & . & . & II 1 & III +-1 & II $1-2$ & $\mathrm{~V}+-1$ \\
\hline Crocus sp. & . & . & $\mathrm{II}+$ & $\mathrm{II}+$ & $\mathrm{I}+$ & . \\
\hline Astragarus sp. 2 & $\mathrm{I}+$ & $\mathrm{II}+$ & IV +-1 & . & . & . \\
\hline Polypogon sp. & III +-1 & . & . & . & . & . \\
\hline Ligularia sp. & $\mathrm{II}+$ & . & . & . & . & . \\
\hline Astragarus nivalis & $\cdot$ & IV +-1 & I 1 & . & . & . \\
\hline Galium verum & $I+$ & $\mathrm{II}+-1$ & I 1 & . & . & . \\
\hline Cirsium sp. & . & II +-1 & . & . & . & $I+$ \\
\hline Tragopogon dubis & . & $\mathrm{II}+$ & . & . & . & I + \\
\hline Tymus serpyllum & I 1 & II +-2 & . & . & . & . \\
\hline Leymus sp. & . & $\mathrm{III}+-1$ & . & . & . & . \\
\hline Chenopodium sp. 1 & . & III +-1 & . & . & . & . \\
\hline Poa pratensis & . & II $2-4$ & . & . & . & . \\
\hline Artemisia sp. 2 & . & II $2-3$ & . & . & . & . \\
\hline Chenopodium sp. 2 & . & II 1 & . & . & . & . \\
\hline Erysimum sp. & . & II + & . & . & . & . \\
\hline Trifolium sp. & . & $\mathrm{II}+$ & . & . & . & . \\
\hline Potentilla sp. 3 & I + & II +-1 & . & . & . & . \\
\hline Bromus sp. & . & III +-1 & IV +-2 & . & . & . \\
\hline Astragarus sp. 3 & . & $\mathrm{II}+$ & III +-2 & . & . & . \\
\hline
\end{tabular}

the total V-value in each plot. We considered the composition of the percentages to be a growth form spectrum (Gimmingham, 1951).

\section{Results}

\section{Phytosociological features}

Table 1 shows the species composition based on the data for consistency and coverage classes. In general, Carex sp., Artemisia sp., Deschampsia caespitosum, and three other species were distributed on all lines with relatively large consistency and coverage classes, and several species within the Poaceae, Asteraceae, and Brassicaceae characterized each line. Only 1 coexisting endemic species was found on south-oriented vegetation lines (S1, S2 and S3), whereas 7 species were found on north-oriented lines (N1, N2 and N3). Regarding the specific species in each line, 13 species were mostly observed on S2 (degenerated vegetation), whereas 1 to 9 species were observed on other lines.

\begin{tabular}{|c|c|c|c|c|c|c|}
\hline Survey No. & 5 & 4 & $\begin{array}{c}1 \\
\end{array}$ & 3 & 2 & 6 \\
\hline \multicolumn{7}{|l|}{ Species name } \\
\hline Stellaria sp. & $\mathrm{I}+$ & . & II + & $\mathrm{I}+$ & . & $\mathrm{I}+$ \\
\hline Rhodiola sp. & . & $\mathrm{I}+$ & II + & . & . & $\mathrm{I}+$ \\
\hline Sausurea sp. & . & . & II + & . & . & $\mathrm{I}+$ \\
\hline Pedicularis sp. & $\mathrm{I}+$ & . & $\mathrm{II}+$ & . & . & . \\
\hline Aster sp.2 & . & $\mathrm{I}+$ & IV +-1 & . & . & . \\
\hline Polygonum sp. & . & $\mathrm{I}+$ & III + & . & . & . \\
\hline Geum sp.1 & . & . & $\mathrm{I}+$ & $\mathrm{V}+-3$ & III + & III + \\
\hline Leontopodium sp. & . & . & $\mathrm{I}+$ & IV +-1 & $\mathrm{II}+-2$ & IV +-1 \\
\hline Trisetum sibiricum & . & . & . & IV +-1 & II +-1 & II +-1 \\
\hline Poa lipskyi & . & . & . & I 1 & II +-1 & V $1-3$ \\
\hline Gentiana sp. & . & . & $\mathrm{I}+$ & IV + & $\mathrm{I}+$ & $\mathrm{II}+$ \\
\hline Cerastium sp. 1 & . & . & . & III + -1 & I 1 & II + \\
\hline Astragarus sp.4 & . & . & I 1 & II $1-2$ & II 1 & II 1 \\
\hline Senecio sp.1 & . & I 1 & . & $\mathrm{IV}+$ & $\cdot$ & III + \\
\hline Geum sp.2 & . & . & . & $\mathrm{II}+$ & . & $\mathrm{IV}+$ \\
\hline Silene sp.1 & . & . & I 1 & $\mathrm{II}+$ & . & $\mathrm{II}+$ \\
\hline Ixeris sp. & $\mathrm{I}+$ & . & . & $\mathrm{II}+$ & . & $\mathrm{II}+$ \\
\hline Phlomis oreophila & . & . & . & IV +-1 & I 1 & . \\
\hline Silene sp.2 & . & . & . & III + & $\mathrm{I}+$ & $\mathrm{I}+$ \\
\hline Draba sp. 2 & . & . & . & III + & . & $\mathrm{I}+$ \\
\hline Aster sp. 3 & . & . & . & $\mathrm{II}+$ & . & $\mathrm{I}+$ \\
\hline Geum sp.3 & . & . & . & II + & . & $\mathrm{I}+$ \\
\hline Cerastium sp. 2 & . & . & . & $\mathrm{II}+$ & . & . \\
\hline unknown sp. & . & . & . & $\mathrm{II}+$ & . & . \\
\hline Polygonum viviparum & . & . & . & $\mathrm{II}+$ & . & . \\
\hline Cerastium sp. 3 & . & . & . & $\mathrm{II}+$ & . & . \\
\hline Ligularia narynensis & . & $\mathrm{I}+$ & . & IV +-1 & II +-1 & . \\
\hline Geranium sp. 2 & . & . & $\mathrm{I}+$ & II +-1 & $\mathrm{II}+$ & . \\
\hline Draba sp.1 & . & . & $\mathrm{I}+$ & . & $\mathrm{II}+$ & . \\
\hline Arabis sp.2 & . & . & $\mathrm{I}+$ & . & $\mathrm{II}+$ & $\mathrm{II}+$ \\
\hline Bupleurum sp. & . & . & $\mathrm{I}+$ & . & $\mathrm{I}+$ & III + -1 \\
\hline Tilingia sp. & . & . & . & . & . & $\mathrm{III}+$ \\
\hline Astragarus sp. 5 & . & . & . & . & . & II $1-2$ \\
\hline Senecio sp.2 & . & . & . & . & . & II +-2 \\
\hline Allium platyspathum & . & . & . & . & . & II + \\
\hline Geranium sp.1 & . & . & . & . & . & $\mathrm{II}+$ \\
\hline
\end{tabular}

The similarities between vegetation lines (CC) are shown in Table 2. The values of CC ranged from 0.309 to 0.339 among south-oriented lines, whereas they ranged from 0.418 to 0.509 among north-oriented lines and the values were significantly larger (t-test, $p<0.01$ ). Between south-oriented lines and north-oriented lines, S1 and S2 had values less than 0.300, but S3 had larger values from 0.319 to 0.463 .

Table 2. Coefficient of community (CC) based on the species composition among the surveyed lines

\begin{tabular}{|c|c|c|c|c|c|c|}
\hline Line No. & S1 & $\mathrm{S} 2$ & S3 & N1 & N2 & N3 \\
\hline S1 & 1 & 0.327 & 0.309 & 0.237 & 0.271 & 0.246 \\
\hline $\mathrm{S} 2$ & & 1 & 0.339 & 0.200 & 0.263 & 0.224 \\
\hline S3 & & & 1 & 0.319 & 0.463 & 0.348 \\
\hline $\mathrm{N} 1$ & & & & 1 & 0.509 & 0.452 \\
\hline N2 & & & & & 1 & 0.418 \\
\hline N3 & & & & & & 1 \\
\hline
\end{tabular}

\section{Biomass and the number of species}

Table 3 shows the parameters related to biomass (vegetation coverage, maximum plant 
Table 3. Average biomass and species richness for each vegetation line

\begin{tabular}{|c|c|c|c|c|c|c|c|c|c|c|}
\hline \multirow[t]{2}{*}{ Measure } & \multicolumn{7}{|c|}{ Line No. } & \multirow[t]{2}{*}{$\mathrm{Se}$} & \multicolumn{2}{|c|}{ Significance by ANOVA } \\
\hline & S1 & S2 & S3 & & N1 & N2 & N3 & & Slope direction & Elevation \\
\hline \multicolumn{11}{|l|}{ Biomass } \\
\hline Vegetation coverage (\%) & $46.3 \mathrm{c}$ & $52.5 \mathrm{bc}$ & 50.6 & $\mathrm{bc}$ & 75.6 a & $63.1 \mathrm{abc}$ & $71.3 \mathrm{ab}$ & 15.0 & $p<0.001$ & $\mathrm{~ns}$ \\
\hline Maximum plant height $(\mathrm{cm})$ & $37.9 \mathrm{ab}$ & 51.4 a & 37.3 & $\mathrm{ab}$ & $28.5 \mathrm{bc}$ & $26.4 \mathrm{c}$ & $25.4 \mathrm{c}$ & 5.7 & $p<0.00001$ & $p<0.006$ \\
\hline V-value $\left(10^{-2} \mathrm{~m}^{3} \cdot \mathrm{m}^{-2}\right)$ & 4.27 & 4.37 & 4.57 & & 3.05 & 3.08 & 3.63 & 1.2 & $p<0.03$ & ns \\
\hline \multicolumn{11}{|l|}{ Species richness } \\
\hline Number of species per plot & $10.1 \mathrm{c}$ & $11.5 \mathrm{bc}$ & 13.6 & $\mathrm{~b}$ & $18.6 \mathrm{a}$ & $11.0 \mathrm{c}$ & $16.4 \mathrm{ab}$ & 3.4 & $p<0.008$ & $p<0.05$ \\
\hline Total number of species & 27 & 38 & 45 & & 46 & 34 & 44 & - & ns & $\mathrm{ns}$ \\
\hline
\end{tabular}

Each record (from N1 to S3) indicates the mean per plot ( $\mathrm{n}=8$ ), except for total number of species.

Different letters in columns denote significantly different means as determined by Tukey's HSD $(p<0.05)$.
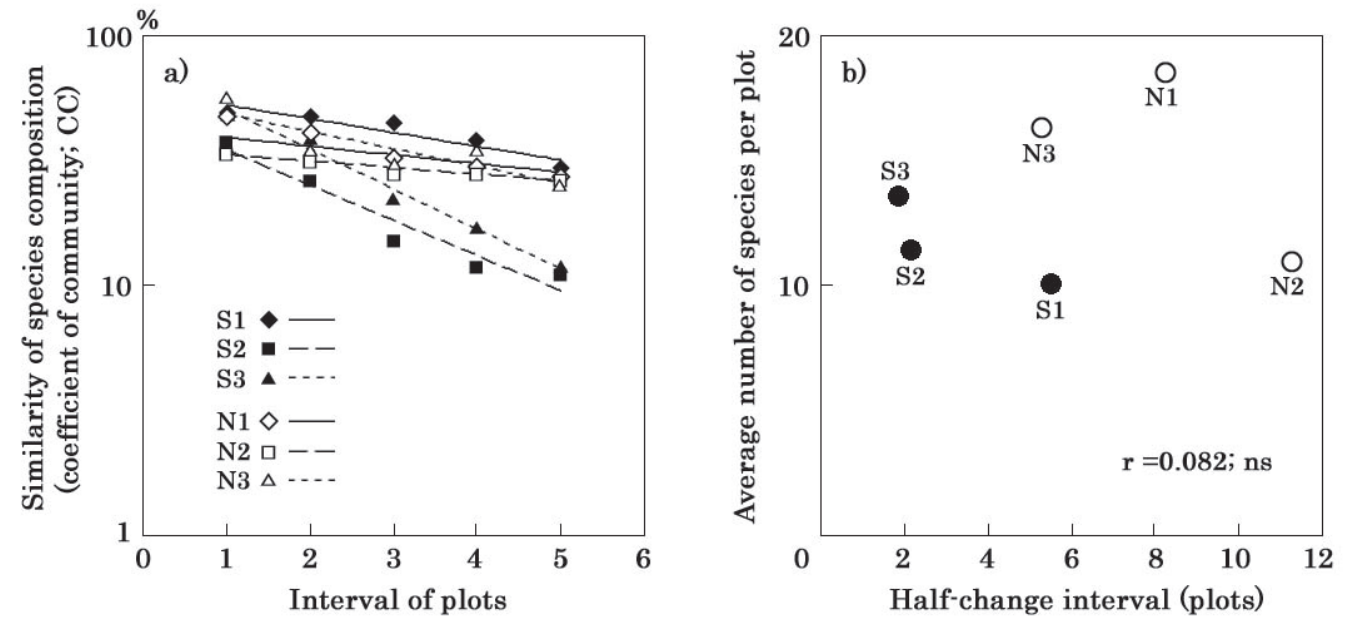

Fig. 6. $\beta$-diversity demonstrated by half-change interval in each vegetation line

a) Decrease in similarity of species composition with increasing interval of plots. The slope of each regression line gives the half-change interval. b) Arrangement of each vegetation line by half-change interval ( $\beta$-diversity) and average number of species per plot ( $\alpha$-diversity).

height, V-value) and number of species (per plot, total). Based on analyses of variance, the slope direction significantly influenced all measures except the total number of species (F-test, $p<$ 0.00001 to 0.03 ), and the elevation zone influenced the maximum plant height and number of species per plot (F-test, $p<0.006$ to 0.05 ). Roughly speaking, vegetation coverage was larger along north-oriented lines than south-oriented lines, and maximum plant height and $\mathrm{V}$-value were larger along south-oriented lines than north-oriented lines. However, no significant differences (Tukey's HSD test) were detected among lines in V-value because of its larger standard error. The number of species per plot tended to decrease at higher elevation on south-oriented lines, but no tendency was observed in north-ori- ented lines.

\section{Changes in species composition along gradient}

Figure $6 \mathrm{a}$ demonstrates the relationship between plot interval and average similarity (on a logarithmic scale). Average similarity decreased with increased plot interval. A significant regression line ( $\mathrm{r}=-0.84$ to $-0.99, p<0.04$ to $0.001, \mathrm{n}$ $=5$ ) was obtained for each vegetation line. The slopes of the regression lines of S2 and S3 $(-0.140$ and -0.160 , respectively) were much steeper than the other lines $(-0.027$ to -0.069$)$, for which analysis of covariance detected a significant difference in the slope of regression lines between the two groups (F-test, $p<0.00005)$. $\mathrm{HC}$ values were also significantly different (t-test, $p<0.03$ ) between 
$\mathrm{S} 2$ and $\mathrm{S} 3(\mathrm{HC}=2.1$ and 1.9 plots, respectively) and the others $(\mathrm{HC}=5.5,8.3,11.3$ and 5.3 plots in S1, N1, N2 and N3, respectively).

Figure $6 \mathrm{~b}$ shows the number of species per plot (alpha diversity) and half-change intervals (beta diversity) in each vegetation line. No relationship was found between alpha and beta diversity, which proved that $\mathrm{HC}$ values for S2 and S3 were small irrespective of the number of species.

\section{Growth form spectrum}

Growth form spectra in all 48 plots (6 vegetation lines $\times 8$ plots) are shown in Fig. 7 . On the whole, 't' overwhelmingly dominated almost all plots, with 'r-e' and 'p-b' noticeable secondarily. The relationship between the total V-value and the percentage of each growth form was not significant ( $\mathrm{r}$ ranged from -0.11 to +0.26 ; $\mathrm{ns}$ ), except for 'b' ( $\mathrm{r}=-0.29$, F-test, $p<0.05$ ). Among the percentages of growth forms relative to each other, a significant correlation was found only between ' $\mathrm{t}$ ' and ' $\mathrm{r}$-e' ( $\mathrm{r}=-0.79$, F-test, $p$ $<0.000002)$.

Comparing S2 (degenerated vegetation) with the others, the percentage of ' $\mathrm{t}$ ' (29 to 69\%) was significantly smaller than the others except for $\mathrm{N} 1$, whereas the percentage of 'r-e' (2 to 62\%) was significantly larger than N2 and N3 (Tukey's HSD test, $p<0.05$ ). In addition, it was odd that ' $\mathrm{b}$ ' occupied more than $45 \%$ of the upper plots of S2. It was also odd that the percentage of 'p-b' was so small in S1 (0.0 to $1.9 \%)$ and S2 (0.6 to 5.4\%), and that S2 lacked any ' $r$ ' in all 8 plots.

\section{Discussions}

\section{Species composition and biomass}

In terms of species composition, biomass and number of species, each of the 6 vegetation lines
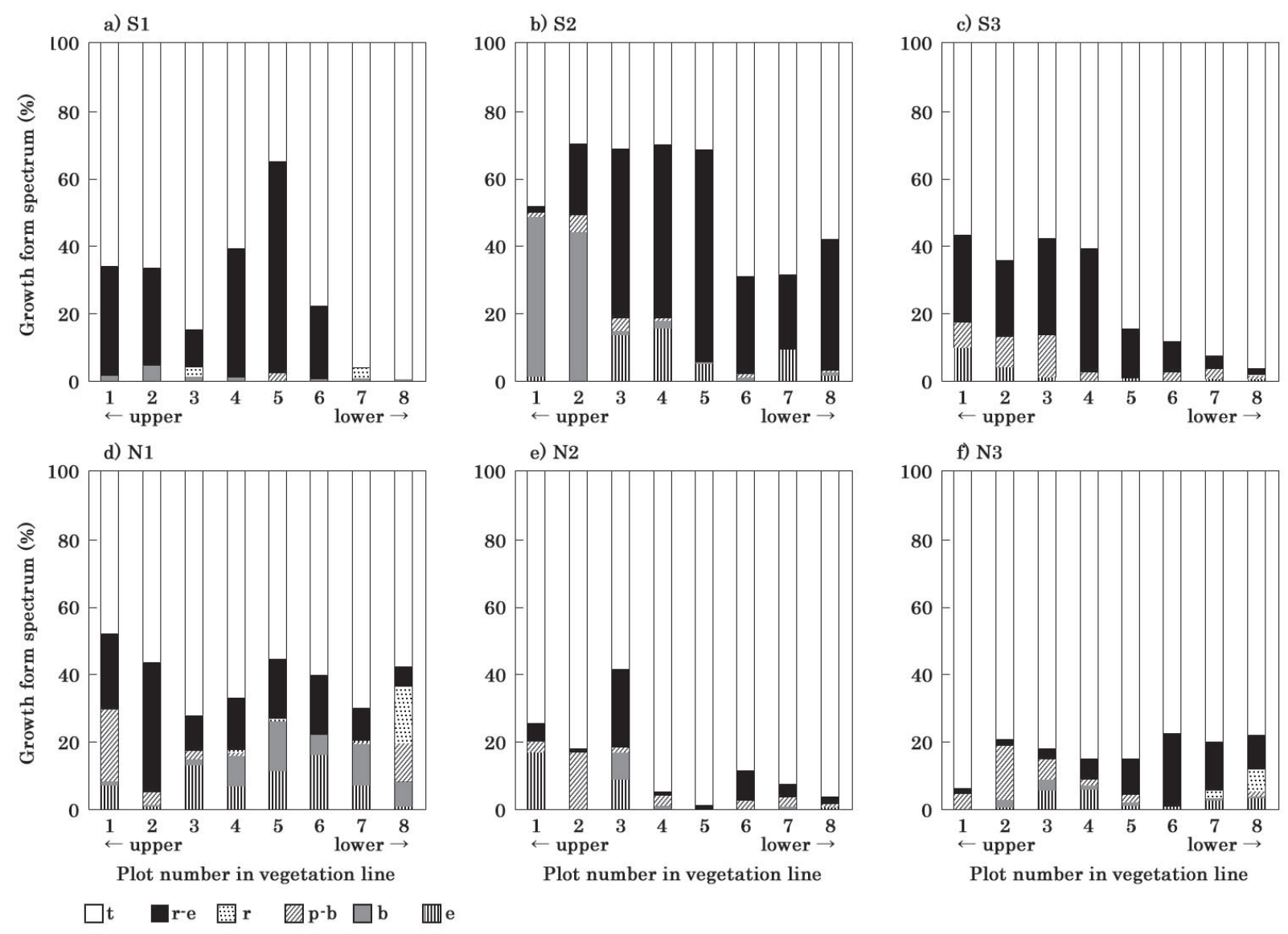

Fig. 7. Growth form spectra expressed as percentage of the V-value of each growth form out of total V-value 
is considered to have been determined to a great extent by geographical factors. Six species were commonly distributed on all lines with relatively large consistency and coverage classes, and several species characterized each line (Table 1). Species composition was similar among south-oriented lines and again among north-oriented lines (Table 2). These observations suggest that the present species composition is a result of continuous variation among the lines having the same slope direction.

The measures concerning biomass (vegetation coverage, maximum plant height and $\mathrm{V}$-value) and number of species per plot were influenced by slope direction, and maximum plant height and number of species per plot were influenced by elevation zone (Table 3 ). Roughly speaking, south-facing slopes were covered with a tall, sparse community, whereas north-facing slopes were covered with a short, dense community. Differences in V-value and total number of species were not significant (Table 3). Therefore, we could not conclude that the vegetation had degenerated in S2 alone, since S2 was also considered to be part of a continuous variation over the entire research area.

In addition, the above observations do not support the conclusion that the vegetation of S2 is consistent with the generally observed impacts of overgrazing. Overgrazing is reported to cause a decrease in plant height and biomass (Painter et al., 1993; Nishiwaki et al. 1999). However, in contrast, height and biomass were larger in S2; low vegetation coverage (i.e., extensive bare ground) was observed not only in S2, but also in all 3 lines of south-direction slopes.

\section{Intensity of change in species composition}

The changes in species composition along the gradient corresponding to differences in microelevation among 8 plots provide interesting information. Replacement of species is consid- ered intensive in S2 and S3, since a slight interval decreased the similarity of species composition (Fig. 6a). This coincides with the observation that there were far fewer common species on south-oriented lines than north-oriented lines (Table 1) and that the values of CC were significantly smaller on south-oriented lines (Table 2). In general, HC is reported to be affected by sample size and to decrease with an increase of alpha diversity (Wilson and Mohler, 1983). However, our research employed the equal plot sizes under a definite experimental design. In addition, there was no relationship between alpha diversity (number of species per plot) and $\mathrm{HC}$ (Fig. 6b). Consequently, excluding S1, we infer that the replacement of species along the gradient is intensive on south-facing slopes, and moderate on north-facing slopes. This suggests that the species composition is apt to change to other vegetation or to degenerate on south-facing slopes due to some kind of pressure.

Recovery of alpine vegetation that is in decline is made difficult by severe environmental conditions (Erschbamer et al., 2001; Kikuchi, 2003; Tamura and Cheng, 2009), and herbivores graze on a limiting area of mountain pastures (Jewel et al., 2005). In addition, dryness and competition among plants tend to be severe on south-facing slopes (Bazzaz, 1996) and slope direction is reportedly often more critical than elevation for the distribution of vegetation (Masuzawa, 1997; Raffl et al., 2006; Sekulová and Hájek, 2009; Arase et al., 2011). These circumstances might be responsible for bringing about the small values of $\mathrm{HC}$ (i.e., intense replacement of species; high beta diversity) on the south-facing slopes. Consequently, it is suspected that vegetation along the south-facing slopes has a high risk of rapid degeneration once a threshold of degeneration occurs.

\section{Growth form spectrum}

Growth form spectra (Fig. 7) showed that S2 is considerably different from other vegetation 
lines; the percentage of ' $t$ ' was small and those of 'r-e' and 'b' were large. In general, plant growth form shifts down to 't,' 'p' and 'r,' which have growing points low to the ground, as an adaptation to grazing (Numata, 1965; Weisel, 1987). In contrast, these forms decreased in S2. Since there was a strong negative correlation between the percentages of ' $t$ ' and 'r-e,' some environmental factors are considered to induce which of the two growth forms will dominate in each plot.

Overgrazing finally gives rise to bare ground and soil deterioration, which allows annual or biennial herbs to invade and dominate (Daubenmire and Colwell, 1942; Kawanabe et al., 1998). However, such phenomena were not observed in S2, where only a few species of Chenopodium existed sporadically. The V-value had a significant negative correlation with the percentage of 'b,' i.e., a decrease of biomass has something to do with the exuberance of ' $b$ '. In the research area, ' $b$ ' comprised mainly Myosotis sp., a Boraginaceae plant. It is possible that the abundance of ' $b$ ' favors the survival and increase of nonpalatable plants as a result of grazing (Cheng et al., 2008).

Although it is true that the growth form spectrum in S2 was dissimilar to the other lines, we cannot attribute the dissimilarity to grazing. Taking the intensity of replacement of species composition into consideration, other environmental factors such as wind and dryness also deserve attention when investigating the cause of degeneration of vegetation.

\section{Acknowledgements}

We would like to thank the National Center for Mountain Regions Development of the Kyrgyz Republic. This study was funded by the Grant-in-Aid for Scientific Research (Grant No. 23251001, Spokesman: Teiji Watanabe). We would like to express our thanks to the people of Sary-Tash Village for their valuable assistance carrying out field surveys.

\section{References}

Arase, T. (2012): Estimation of seasonal changes in the biomass of forest floor vegetation in a larch forest at the northern foot of Mt. Fuji, Japan. Journal of Environmental Information Science, 40, 23-30.

Arase, T., Izumiyama, S., Watanabe, T. and Anarbaev, M. (2011): Survey of alpine steppe vegetation in the Koyondu Valley, Sarychat-Ertash State Reserve in the northern Tian Shan Mountains of the Kyrgyz Republic. Bulletin Shinshu University Alpine Field Center, 9, 75-82. [in Japanese with English summary]

Bazzaz, F. A. (1996) Plants in changing environment. Cambridge University Press, Cambridge.

Cheng, Y., Tsendeekhuu, T., Nakamura, N. and Nakamura, T. (2008): Phytosociological study of steppe vegetation in Mongolia. Grassland Science, 54, 107-116.

Chibilev, A.A. and Bogdanov, S.V. (2009): The legacy of nomadic empires in steppe landscapes of northern Eurasia. Herald of the Russian Academy of Sciences, 79, 823-830.

Daubenmire, R.F. and Colwell, W.E. (1942): Some edaphic changes due to overgrazing in the Agropyron-Poa prairie of south-eastern Washington. Ecology, 23, $32-40$.

Erschbamer, B., Kneringer, E. and Schlag, N. (2001): Seed rain, soil seed bank, seedling recruitment, and survival of seedlings on a glacier foreland in the Central Alps. Flora, 196, 304-312.

Gimingham, C.H. (1951): The use of life form and growth form in the analysis of community structure, as illustrated by a comparison of two dune communities. Journal of Ecology, 39, 396-406.

Jewel, P.L., Güsewell, S., Berry, N.R., Käuferle, D., Kreuzer, M. and Edwards, P. (2005): Vegetation patterns maintained by cattle grazing on a degraded mountain pasture. Botanica Helvetica, 115, 109-124.

Kawada, K., Vovk, A.G., Filatova, O.V., Araki, M., Nakamura, T. and Hayashi, I. (2005): Floristic composition and plant biomass production of steppe communities in the vicinity of Kharkiv, Ukraine. Grassland Science, 51, 205-213.

Kawagoe, H. and Baba, T. (1992): Plant communities at Shinshu University's forest in Nobeyama. Journal of 
the Faculty of Agriculture Shinshu University, 47-88. [in Japanese with English summary]

Kawamura, K., Akiyama, T., Yokota, H., Yasuda, T., Tsutsumi, M., Watanabe, O. and Wang, S. (2005): Conservation and sustainable use of grassland ecosystems -application of satellite monitoring and GPS/GIS-. Japanese Journal of Ecology, 55, 327-335. [in Japanese〕 Kawanabe, S., Nan, Y., Oshida, T., Kou, Z., Jiang, D., Takada-Oikawa, N. and Mukaiyama, S. (1998): Degeneration of grassland in Keerqin Sandland, Inner Mongolia, China. Grassland Science, 44, 109-114.

Kawanabe, S. and Zhu, T. (1991): Degeneration and conservational trial of Aneurolepidium chinense grassland in northern China. Journal of Japanese Society of Grassland Science, 37, 91-99.

Kikuchi, T. (2003): Pattern of periglacial geomorphology and alpine vegetation. Iden, 57, 44-47. [in Japanese]

Li, X.F., Wang, J. and Huang, D. (2011): Allelopathic potential of Artemisia frigida and successional changes of plant communities in the northern China steppe. Plant and Soil, 341, 383-398.

Masuzawa, T. (1997): Ecology of the alpine plants. University of Tokyo Press, Tokyo. [in Japanese]

Nishiwaki, A., Sato, S., Otake, H., Shinohara, H. and Sugawara, K. (1999): The comparison of pasture vegetation between two dairy farms under different grazing managements. Grassland Science, 45, 52-58. [in Japanese with English summary]

Numata, M. (1965): Ecological judgment of grassland condition and trend I. Judgment by biological spectra. Journal of Japanese Society of Grassland Science, 11, 20-33. [in Japanese with English summary]

Painter, E.L., Detling, J.K. and Steingraeber, D.A. (1993): Plant morphology and grazing history: relationship between native grass and herbivores. Vegetatio, 106, $37-62$.

Raffl, C., Mallaun, M., Mayer, R. and Erschbamer, B. (2006): Vegetation succession pattern and diversity changes in a glacier valley, Central Alps, Austria. Arctic, Antarctic, and Alpine Research, 38, 421-428.

Schmidt, M. (2005): Utilization and management changes in south Kyrgyzstan's mountain forests. Journal of Mountain Science, 2, 91-104.

Sekulová, L. and Hájek, M. (2009): Diversity of subalpine and alpine vegetation of the earstern part of the Nízke Tatry Mts in Slovakia: major types and environmental gradients. Biologia, 64, 908-918.

Taft, J.B., Phillippe, L.R., Dietrich, C.H. and Robertson, K.R. (2011): Grassland composition, structure, and diversity patterns along major environmental gradients in the central Tien Shan. Plant Ecology, 212, 1349-1361.

Tamura, K. and Cheng, Y. (2009): Soil and vegetation in arid region. In: Shinoda, M. editor. Nature in arid region. Kokon Shoin Press, Tokyo, pp69-92. 〔in Japanese]

Watanabe, T., Anarbaev, M. and Iwata, S. (2008): Protected areas and tourism development in the Kyrgyz Republic. Geographical Studies, 83, 29-39. [in Japanese]

Weisel, Y. (1987): Evolution of elect growth forms in domesticated wheats: possible effects of grazing. Oecologia (Berlin), 73, 630-632.

Whittaker, R.H. (1960): Vegetation of the Siskiyou Mountains, Oregon and California. Ecological Monograph, 30, 279-338.

Wilson, M.V. and Mohler, C.L. (1983): Measuring compositional change along gradients. Vegetatio, 54, 129-141.

(Accepted on 29 August 2013) 